\title{
Analisis kebutuhan pengembangan LKPD berbasis $P O E$ berbantuan augmented reality untuk melatihkan keterampilan proses dasar pada konsep fluida statis

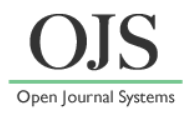

\author{
Okta Briyanti Mila Sari*, Eko Risdianto, Sutarno \\ Prodi Pendidikan Fisika FKIP, Universitas Bengkulu \\ J1. WR. Supratman, Bengkulu 38123 \\ *Email: oktabriyantimilasari3@gmail.com
}

DOI: https://doi.org/10.33369/pendipa.4.2.85-93

\begin{abstract}
[Analysis of the development needs of students' worksheets based on POE assisted by augmented reality to practice basic process skills in the concept of static fluids] The purpose of this study is to describe the analysis of the development needs of students' worksheets based on predict-observe-explain assisted by augmented reality to practice basic process skills in the concept of static fluids. This type of research is research and development $(R \& D)$ research using $3 D$ research methods (define, design, develop). Researchers limit this research to define stage. At the LKPD the predict stage will be displayed at the beginning of the LKPD as the initial hypothesis before conducting the experiment. Observe stage carried out experiments to prove the hypothesis. While in the explain step, several questions are presented to compare predict and observe. The augmented reality LKPD is shown in predict illustrations, display of experimental tools and materials, and experimental steps. This is so that students better understand the experimental activities that will be carried out. Based on the results of the research conducted it can be concluded that students need POE-based LKPD based on augmented reality. This is based on data obtained that $71.43 \%$ of students answered Agree to the need for the development of an augmented reality POE-based LKPD, with a validity value of 2.754 in the quite valid category and a Cronbach's alpha reliability count of 0.928 with $r$ count $>r$ table $(d k 53=d k 53=0.2725)$ so that the questionnaire needs of students are reliable.
\end{abstract}

Keywords: LKPD, POE, augmented reality, basic process skills, static fluids.

\begin{abstract}
ABSTRAK
Tujuan dari penelitian ini adalah mendeskripsikan analisis kebutuhan pengembangan lembar kerja peserta didik berbasis predict-observe-explain berbantuan augmented reality untuk melatihkan keterampilan proses dasar pada konsep fluida statis. Jenis penelitian ini adalah penelitian research and development $(\mathrm{R} \&$ D) dengan menggunakan metode penelitian 3D (define, design, develop). Peneliti membatasi penelitian ini sampai tahap define. Pada LKPD tahap predict akan ditampilkan pada awal LKPD sebagai hipotesis awal sebelum melakukan percobaan. Tahap observe dilakukan percobaan untuk membuktikan hipotesis. Sedangkan pada tahap explain disajikan beberapa pertanyaan untuk membandingkan predict dan observe. Pada LKPD augmented reality ditampilkan pada ilustrasi predict, tampilan alat dan bahan percobaan, serta langkah percobaan. Hal ini supaya peserta didik lebih memahami kegiatan percobaan yang akan dilakukan. Berdasarkan hasil penelitian yang dilakukan dapat disimpulkan bahwa peserta didik membutuhkan LKPD berbasis $P O E$ berbantuan augmented reality. Hal ini di dasarkan data yang diperoleh bahwa 71,43\% peserta didik menjawab Setuju diperlukannya pengembangan LKPD berbasis POE berbantuan augmented reality, dengan nilai kevalidan 2,754 dalam kategori cukup valid dan nilai relialibitas alfa cronbach hitung 0,928 dengan $\mathrm{r}$ hitung $>\mathrm{r}$ tabel $(\mathrm{dk} 53=0,2725)$ sehingga angket kebutuhan peserta didik reliabel.
\end{abstract}

Kata kunci: LKPD, POE, augmented reality, keterampilan proses dasar, fluida statis 


\section{PENDAHULUAN}

Pendidikan merupakan usaha sadar dan terencana untuk mewujudkan suasana belajar dan proses pembelajaran agar peserta didik secara aktif mengembangkan potensi dirinya untuk memiliki kekuatan spiritual keagamaan, pengendalian diri, kepribadian, kecerdasan, akhlak mulia, serta keterampilan yang diperlukan dirinya, masyarakat, bangsa, dan negara (Putri et al., 2017). Sedangkan menurut Ningrum (Ningrum \& Suparman, 2017) pendidikan adalah suatu proses dalam rangka mempengaruhi peserta didik agar dapat menyesuaikan diri sebaik mungkin. Selain itu pendidikan juga sebagai dasar dalam mengembangkan suatu potensi yang dimiliki oleh peserta didik dalam upaya menghantar peserta didik menuju citacitanya dan bertanggung jawab terhadap semua yang dilakukannya. Oleh karena itu, butuh upaya untuk meningkatkan kualitas pendidikan dalam proses pembelajaran, sebagaimana yang diharapkan dalam Kurikulum 2013.

Pembelajaran dalam kurikulum 2013 adalah pembelajaran kritis, dimana peserta didik dituntut untuk aktif, kritis, inovatif dan kreatif selama proses pembelajaran (Anggraini et al., 2017). Akan tetapi berdasarkan hasil observasi yang diperoleh menunjukkan bahwa proses pembelajaran di kelas belum maksimal dalam menjalankan kurikulum 2013 seperti pada kegiatan proses pembelajaran di sekolah sudah menggunakan media pembelajaran seperti powerpoint dan video pembelajaran akan tetapi media tersebut belum mampu membantu siswa dalam memahami materi karena hanya berupa tulisan yang sama seperti dibuku. Selain itu bahan ajar seperti lembar kerja peserta didik (LKPD) yang digunakan oleh guru masih banyak yang belum termasuk bahan ajar ideal karena LKPD yang digunakan oleh sekolah-sekolah saat ini tidak melatih peserta didik untuk melakukan proses penyelidikan karena hanya berisi kumpulan soal yang harus dikerjakan peserta didik, LKPD biasanya hanya berupa langkahlangkah atau petunjuk untuk menyelesaikan suatu permasalahan tanpa memperhatikan tujuan pembelajaran sehingga pembelajaran yang seperti ini dikhawatirkan akan membuat peserta didik cenderung pasif dan berdampak pada kurangnya pengetahuan dan keterampilan yang peserta didik peroleh.

Oleh sebab itu diperlukannya suatu inovasi dalam proses pembelajaran untuk mengatasi permasalahan tersebut, salah satunya dengan pembuatan bahan ajar sesuai dengan tuntutan kurikulum 2013 dan karakteristik materi yang disampaikan. Berdasarkan permasalahan LKPD tersebut penulis mendapatkan titik fokus untuk mengembangkan LKPD dengan mempertimbangkan aspek-aspek LKPD ideal dan menggunakan teknologi terbaru untuk pembelajaran fisika.

LKPD ideal adalah LKPD yang dikembangkan sesuai dengan model pembelajaran yang digunakan pada saat pembelajaran sehingga LKPD ini akan efektif, berhasil, memuaskan, dan bermakna. Penggunaan teknologi terbaru yang sesuai dengan era revolusi 4.0 juga sebagai salah satu media pembelajaran yang dapat digunakan dalam membuat LKPD menjadi ideal. Salah satu teknologi terbaru pada era revolusi 4.0 yaitu virtual reality, e-learning, dan augmented relity. Peneliti pada penelitian ini tidak menggunakan virtual reality dan e-learning karena virtual reality membutuhkan $V R$ box dalam penggunaannya yang jarang dimiliki oleh siswa, sedangkan e-learning membutuhkan internet dalam penggunaannya. Penggunaan LKPD dan media pembelajaran ini ditujukan agar peserta didik terlihat aktif dan memahami materi sendiri dalam pembelajaran (Muna, 2017). Oleh karena itu, untuk mendukung proses pembelajaran yang efektif dan peserta didik aktif salah satunya dengan menggunakan LKPD bermodel pembelajaran Predict-Observe-Explain (POE) dan menggunakan teknologi augmented reality sebagai salah satu perkembangan teknologi dalam era revolusi industri 4.0.

LKPD berbasis POE dengan menggunakan teknologi augmented reality merupakan lembar kerja yang di dalamnya terdapat langkah-langkah POE yaitu meliputi proses membuat dugaan terhadap suatu peristiwa (predict), melakukan pengamatan apa yang terjadi (observation), pemberian penjelasan terhadap kesesuaian tahap observasi dengan dugaan hasil pengamatan (explanation) dan dalam langkah tersebut akan 
dimasukkan teknologi augmented reality yang mampu menggabungkan benda maya dua dimensi atau tiga dimensi ke dalam sebuah lingkungan yang nyata kemudian memunculkannya atau memproyeksikannya secara real time (Mustaqim, 2016).

Atas dasar pentingnya penggunaan LKPD untuk pembelajaran fisika dan beberapa kelebihan yang terdapat pada model pembelajaran POE dan penggunaan augmented reality, maka pada penelitian ini akan pengembangan LKPD berbasis POE berbantuan teknologi augmented reality sebagai upaya untuk menciptakan pembelajaran yang sesuai dengan kurikulum 2013 yang menyarankan aktivitas sains berupa keterampilan proses sains. Selain itu, LKPD berbasis POE dapat dijadikan sebagai salah satu alternatif dalam menciptakan belajar berkualitas dan menyenangkan. Hal ini sesuai dengan hasil penelitian Muna (2017) menunjukkan bahwa "model pembelajaran POE dapat meningkatkan pemahaman konsep dan keterampilan proses pembelajaran IPA". Hasil penelitian Anggarini (2017) juga menunjukkan bahwa "Lembar Kerja Siswa (LKS) Fisika Berbasis POE Materi Gerak dapat meningkatkan kemampuan berpikir kritis". Hal ini didukung oleh hasil penelitian Fakhrudin et al. (2019) bahwa "Augmented reality dapat mudah digunakan dan menarik minat belajar". Hasil penelitian Mustaqim (2016) juga menunjukkan bahwa "Augmented reality dapat merangsang pola pikir peserta idik dalam berpikir kritis terhadap suatu masalah".

Berdasarkan permasalahan dan fakta-fakta dilapangan serta penelitian yang relevan, pada penelitian ini akan dilakukan pengembangan LKPD berbasis POE dengan bantuan teknologi augmented reality yang belum pernah diterapkan oleh sekolah. LKPD yang dihasilkan diharapkan dapat melatihkan keterampilan proses dasar siswa pada materi fluida statis.

Sebelum memutuskan pembuatan LKPD ini, permasalahan dilapangan masih memerlukan analisis lebih lanjut dan mendalam untuk melihat permasalahan yang ada serta penyebab, kendala dan kekurangan dari bahan ajar dan media yang telah digunakan disekolah. Rangkaian analisis ini diharapkan dapat memberikan gambaran mengenai persepsi peserta didik terhadap proses pembelajaran dikelas serta gambaran permasalahannya sehingga dapat memberikan solusi dan rekomendasi pengembangan bahan ajar berupa LKPD yang dapat membantu proses pembelajaran jika dibutuhkan. Berdasarkan pemaparan diatas, maka rumusan masalah dalam penelitian ini adalah perlukah LKPD berbasis POE berbantuan Augmented Reality untuk melatihkan keterampilan proses dasar pada konsep fluida statis?. Sehingga berdasarkan rumusan masalah penelitian ini bertujuan untuk melakukan analisis kebutuhan terhadap LKPD berbasis $P O E$ berbantuan Augmented Reality untuk melatihkan keterampilan proses dasar pada konsep fluida statis.

\section{METODE PENELITIAN}

\section{Waktu dan Lokasi Penelitian}

Penelitian ini dilaksanakan di SMA Negeri 8 Kota Bengkulu. Waktu penelitian pada tanggal 1 november 2019 sampai dengan 19 november 2019 semester ganjil tahun ajaran 2019/2020.

Populasi dan Sampel

Populasi merupakan wilayah generalisasi yang terdiri dari obyek atau subyek yang mempunyai kualitas dan karakteristik tertentu yang ditetapkan oleh peneliti untuk dipelajari dan kemudian ditarik kesimpulan (Sugiyono, 2010). Populasi penelitian ini diambil dari peserta didik kelas XI MIPA dengan jumlah peserta didik yaitu 140 peserta didik. Sedangkan sampel merupakan sebagian atau wakil populasi yang akan diteliti (Sugiyono, 2013). Dalam pengambilan sampel ini, peneliti menggunakan purposive sampling. Teknik ini digunakan jika dalam teknik penentuan sampel berdasarkan pertimbangan tertentu. Sampel yang diambil sebanyak 55 peserta didik dari kelas XI MIPA 1 dan XI MIPA 3.

\section{Teknik Pengumpulan Data}

Teknik pengumpulan data yang digunakan dalam penelitian analisis kebutuhan ini terdiri dari tiga bagian yaitu metode review dokumen, metode observasi, metode angket dan metode studi literatur. Review dokumen digunakan untuk memperoleh gambaran kurikulum 2013 dan komponen LKPD yang digunakan disekolah. Observasi dilakukan untuk mengamati pelaksanaan pembelajaran dikelas baik pengamatan peran guru sebagai fasilitator yang membelajarkan peserta didik maupun aktivitas peserta didik dalam mendapatkan 
pengetahuannya serta mengamati kendala yang dihadapi. Angket digunakan untuk mengungkapkan karakteristik peserta didik, respon peserta didik terhadap pembelajaran fisika dan spesifikasi sumber belajar yang diinginkan.

\section{Instrumen Penelitian}

Instrumen penelitian yang digunakan dalam penelitian analisis kebutuhan ini adalah lembar review dokumen, lembar observasi, lembar angket kebutuhan peserta didik dan literatur yang berkaitan dengan LKPD, model pembelajaran $P O E$, agmented reality dan keterampilan proses dasar.

Tabel 1 Instrumen Penelitian

\begin{tabular}{|c|c|c|c|c|}
\hline $\begin{array}{c}\text { Tahap } \\
\text { Penelitian }\end{array}$ & Target Data & $\begin{array}{c}\text { Sumber } \\
\text { Data }\end{array}$ & Instrumen & $\begin{array}{c}\text { Analisis } \\
\text { Data }\end{array}$ \\
\hline \multirow[t]{4}{*}{ Define } & $\begin{array}{l}\text { Memperoleh } \\
\text { gambaran } \\
\text { komponen } \\
\text { kurikulum }\end{array}$ & $\begin{array}{l}\text { Dokumen } \\
\text { kurikulum }\end{array}$ & $\begin{array}{l}\text { Lembar } \\
\text { Review } \\
\text { Dokumen }\end{array}$ & $\begin{array}{l}\text { Analisis } \\
\text { Deskriptif }\end{array}$ \\
\hline & $\begin{array}{l}\text { Memperoleh } \\
\text { gambaran } \\
\text { komponen } \\
\text { LKPD yang } \\
\text { biasa } \\
\text { digunakan di } \\
\text { sekolah } \\
\end{array}$ & $\begin{array}{l}\text { Dokumen } \\
\text { LKPD }\end{array}$ & $\begin{array}{l}\text { Lembar } \\
\text { Review } \\
\text { Dokumen }\end{array}$ & $\begin{array}{l}\text { Analisis } \\
\text { Deskriptif }\end{array}$ \\
\hline & $\begin{array}{l}\text { Memperoleh } \\
\text { gambaran } \\
\text { pelaksanaan } \\
\text { pembelajaran } \\
\text { di kelas }\end{array}$ & $\begin{array}{l}\text { Peserta } \\
\text { didik dan } \\
\text { guru }\end{array}$ & $\begin{array}{l}\text { - Lembar } \\
\text { observa } \\
\text { si }\end{array}$ & \\
\hline & $\begin{array}{l}\text { Kebutuhan } \\
\text { akan } \\
\text { pengembangan } \\
\text { LKPD } \\
\text { berbasis POE } \\
\text { berbantuan } \\
\text { augmented } \\
\text { reality }\end{array}$ & $\begin{array}{l}\text { Peserta } \\
\text { didik }\end{array}$ & $\begin{array}{l}\text { - Lembar } \\
\text { angket }\end{array}$ & $\begin{array}{l}\text { Analisis } \\
\text { deskriptif } \\
\text { Analisis } \\
\text { kuantitatif } \\
\text { dan } \\
\text { kualitatif }\end{array}$ \\
\hline
\end{tabular}

\section{Teknik Analisis Data}

Teknik analisis data yang digunakan dalam penelitian ini adalah teknis analisis deskriptif, analisis kualitatif, dan analisis kuantitatif. Analisis data lembar riview dokumen menggunakan teknik analisis deskriptif. Analisis deskriptif digunakan untuk menganalisa data dengan cara mendeskripsikan data yang telah terkumpul sebagaimana adanya tanpa bermaksud membuat kesimpulan yang berlaku untuk umum atau generalisasi. Pada penelitian ini teknik analisis deskriptif berupa deskripsi kualitatif yaitu pemaparan data hasil review dokumen yang berupa komponen kurikulum dan komponen LKPD. Lembar Observasi yang dilakukan pada penelitian ini bertujuan untuk mengetahui gambaran keterlaksanaan LKPD saat praktikum di sekolah serta untuk mengetahui ketercapaian keterampilan proses dasar peserta didik berdasarkan kegiatan yang ada di LKPD. Analisis hasil observasi dilakukan dengan teknik analisis deskriptif, yaitu dengan menafsirkan data hasil observasi yang berupa kegiatan yang ada di LKPD seperti kegiatan memprediksi, mengobservasi atau melakukan pratikum, menjawab pertanyaan, maupun menjelaskan hasil dari partikum. Analisis data kebutuhan peserta didik yang digunakan adalah analisis persentase. Pedoman angket dilakukan dalam bentuk skala deskriptif pada Tabel 2.

Tabel 2 Perhitungan Skala Likert

\begin{tabular}{cc}
\hline Penilaian & Nilai Skala \\
\hline Sangat Setuju & 4 \\
\hline Setuju & 3 \\
\hline Tidak Setuju & 2 \\
\hline Sangat Tidak Setuju & 1
\end{tabular}

Untuk menghitung persentase tersebut menggunakan rumus:

$$
P R S=\frac{\sum S P}{\sum S M} \times 100 \%
$$

Keterangan:

PRS $=$ Persentase Respon Peserta didik

$\mathrm{SP}=$ Skor Perolehan

$\mathrm{SM}=$ Skor Maksimum (Bakri et al., 2015)

Tabel 3 Inperpretasi Skor Respon Peserta didik

\begin{tabular}{cc}
\hline Persentase (\%) & Kategori \\
\hline $0 \%-25 \%$ & Sangat Tidak Setuju \\
\hline $26 \%-50 \%$ & Tidak Setuju \\
\hline $51 \%-75 \%$ & Setuju \\
\hline $76 \%-100 \%$ & Sangat Setuju \\
\hline
\end{tabular}

Analisis kevalidan angket kebutuhan peserta didik dilakukan dengan langkah-langkah Zeila et al. (2014) sebagai berikut.

a) Melakukan rekapitulasi data penilaian kevalidan model kedalam tabel yang meliputi aspek $\left(\mathrm{A}_{\mathrm{i}}\right)$, indikator $\left(\mathrm{I}_{\mathrm{ji}}\right)$ dan validasi $\left(\mathrm{V}_{\mathrm{ji}}\right)$ dari setiap validator berdasarkan tabel 3 . 
b) Menentukan rata-rata nilai hasil dari semua validator untuk setiap indikator dengan menggunakan persamaan 2 .

$I_{j i}=\frac{\sum_{j=1}^{n} V_{j i}}{n}$

Menentukan rata-rata nilai untuk setiap aspek dengan menggunakan persamaan 3 .

$$
A_{i}=\frac{\sum_{j=1}^{n} I_{j i}}{m}
$$

$\mathrm{A}_{\mathrm{i}}$ adalah rata-rata nilai untuk setiap aspek ke$\mathrm{i}$; $\mathrm{I}_{\mathrm{ji}}$ adalah rata-rata untuk aspek ke-i terhadap indikator ke-j; dan $\mathrm{m}$ adalah banyaknya indikator dalam aspek ke-i.

c) Menentukan nilai rata-rata total $V_{a}$ untuk semua aspek dengan menggunakan persamaan 4 .

$$
V_{a}=\frac{\sum_{j=1}^{n} A_{i}}{n}
$$

$\mathrm{V}_{\mathrm{a}}$ adalah nilai rata-rata total untuk semua aspek; $A_{i}$ adalah rata-rata nilai untuk aspek ke-i; dan $\mathrm{n}$ adalah banyaknya aspek.

d) Nilai $V_{a}$ atau rata-rata total ditunjukkan pada interval penentuan tabel 4.

Tabel 4 Tingkat Kelayakan

\begin{tabular}{|l|l|l|}
\hline No & Besarnya & Kriteria \\
\hline 1 & $1 \leq V_{a}<2$ & Tidak Valid \\
\hline 2 & $2 \leq V_{a}<3$ & Cukup Valid \\
\hline 3 & $3 \leq V_{a}<4$ & Valid \\
\hline
\end{tabular}

Analisis reliabilitas angket kebutuhan peserta didik menggunakan reliabilitas Alfa Cronbach sebagai berikut.

$$
r_{i}=\frac{k}{k-1}\left\{1-\frac{\Sigma s_{i}^{2}}{s_{t}^{2}}\right\}
$$

$\mathrm{r}_{\mathrm{i}}=$ koefisien reliabilitas alfa cronbach

$\mathrm{k}=$ jumlah item soal

$\Sigma s_{i}^{2}=$ jumlah varians skor tiap item

$s_{t}^{2}=$ varians total

Jika koefisien reliabilitas alfa cronbach hitung $\left(\mathrm{r}_{\mathrm{i}}\right)$ lebih besar daripada koefisien alfa cronbach tabel $(\mathrm{dk}=\mathrm{k}-2)$ maka instrumen reliabel (Yusup, 2018).

\section{HASIL DAN PEMBAHASAN}

Analisis kebutuhan bertujuan untuk mengumpulkan informasi mengenai permasalahan yang terdapat dalam pembelajaran fisika serta penyebabnya, pelaksanaan pembelajaran serta kendala yang terjadi, penggunaan bahan ajar dan kekurangannya (Yudhi, 2017). Hasil analisis kebutuhan dijadikan sebagai dasar menentukan alternatif solusi dan rekomendasi spesifikasi bahan lembar kerja peserta didik yang akan dikembangkan. Pada review dokumen kurikulum dan LKPD menunjukkan bahwa LKPD yang digunakan di sekolah belum memenuhi kualifikasi kurikulum 2013 Karena hanya terdapat tujuan pembelajaran, alat dan bahan, langkah percobaan dan beberapa pertanyaan. Sehingga dalam pelaksanaan pembelajaran peserta didik masih belum memahami keterkaitan dengan konsep materi yang akan diajarkan. Sehingga dibutuhkan LKPD yang dapat mengarahkan peserta didik menjawab tujuan pembelajaran dengan memberikan prediksi atau hipotesis terhadap permasalahan yang berkaitan dengan percobaan. Selain itu pertanyaan yang terdapat di LKPD yang digunakan juga belum sesuai untuk mengaitkan prediksi dengan percobaan sehingga diperlukan pertanyaan yang dapat mengarahkan peserta didik memahami konsep yang diajarkan.

Dalam pelaksanaan percobaan peserta didik juga mengalami kendala dalam memahami percobaan karena minimnya pengetahuan siswa terhadap alat dan bahan yang digunakan serta setiap langkah percobaan yang tertera di LKPD belum bisa mengarahkan siswa dalam melakukan percobaan sehingga siswa membutuhkan video pembelajaran untuk membantu pelaksanaan percobaan tersebut. Sehingga peneliti memberikan alternatif yaitu menggunakan augmented reality (video pembelajaran tiga dimensi) yang akan diikutsertakan di dalam LKPD.

Sehingga berdasarkan review dokumen dan observasi siswa membutuhkan LKPD yang memuat tahapan prediksi, observasi, dan penjelasan dan dibantu dengan augmented reality untuk membantu siswa lebih memahami kegiatan percobaan. Pada analisis angket kebutuhan peserta didik digunakan untuk menguatkan hasil review dokumen dan observasi peneliti terhadap solusi dalam pelaksanaan pembelajaran yaitu 
pelaksanaan pratikum (percobaan) yaitu pemggembangan LKPD berbasis POE berbantuan augmented reality dan peneliti memberikan angket kepada 55 orang peserta didik kelas XI MIPA.

Gambaran respon peserta didik terhadap mata pelajaran fisika dikelas menggunakan 4 butir pertanyaan, seperti ditunjukkan pada tabel 3. Secara umum peserta didik menyatakan menyukai mata pelajaran fisika, hal ini ditunjukkan dengan respon peserta didik sebesar $67,27 \%$. Namun demikian walaupun hampir separuh peserta didik setuju menyukai mata pelajaran fisika tetapi saat proses pembelajaran berlangsung peserta didik masih merasa tidak bersemangat $(71,82 \%)$ dan bosan $(69,55 \%)$. Hal ini mengakibatkan $60,91 \%$ peserta didik merasa kesulitan dalam memahami pelajaran fisika. Sehingga secara keseluruhan peserta didik setuju bahwa mata pelajaran fisika cukup membosankan dan kurang menyenangkan. Hal ini sejalan dengan hasil penelitian Yulia (2018) bahwa pembelajaran fisika dalam penyampaian materi lebih terkesan monoton.

Tabel 5 Respon Peserta didik Terhadap mata Pelajaran Fisika

\begin{tabular}{|c|c|c|c|}
\hline \multirow{2}{*}{ Item } & \multicolumn{2}{|c|}{ Persentase } & \multirow[t]{2}{*}{ Kriteria } \\
\hline & + & - & \\
\hline $\begin{array}{lr}\text { Peserta } & \text { didik } \\
\text { menyukai } & \text { pelajaran } \\
\text { fisika } & \\
\end{array}$ & $\begin{array}{c}67,27 \\
\%\end{array}$ & & Setuju \\
\hline $\begin{array}{lr}\text { Peserta didik tidak } \\
\text { bersemangat ketika } \\
\text { pelajaran fisika } \\
\text { sedang berlangsung } \\
\text { dikelas }\end{array}$ & & $\begin{array}{c}71,82 \\
\%\end{array}$ & Setuju \\
\hline $\begin{array}{l}\text { Peserta didik selalu } \\
\text { kesulitan memahami } \\
\text { pelajaran fisika }\end{array}$ & & $\begin{array}{c}60,91 \\
\%\end{array}$ & Setuju \\
\hline $\begin{array}{l}\text { Peserta didik merasa } \\
\text { bosan } \\
\text { pembelajaran } \\
\text { sedikika } \\
\text { sedang berlangsung }\end{array}$ & & $\begin{array}{c}69,55 \\
\%\end{array}$ & Setuju \\
\hline
\end{tabular}

Gambaran respon peserta didik mengenai LKPD yang diterapkan dikelas dieksplorasi menggunakan 3 pertanyaan dalam angket, seperti ditunjukkan pada tabel 4. Terlihat bahwa guru sudah menggunakan bahan ajar berupa LKPD saat proses pembelajaran berlangsung. Hal ini ditunjukkan dengan respon peserta didik sebesar
$79,09 \%$. Akan tetapi $61,36 \%$ peserta didik setuju bahwa penggunaan LKPD yang diberikan oleh guru masih belum membantu peserta didik dalam memahami materi baik dari segi konsep maupun keterampilan proses peserta didik. karena LKPD yang digunakan dikelas hanya berupa langkah-langkah dan pertanyaan yang wajib dijawab peserta didik tanpa membuat peserta didik berpikir mengenai permasalahan dalam konsep materi yang akan diajarkan sehingga peserta didik hanya selintas dalam mendapatkan materi tanpa mendalami lebih lanjut. Hal ini sejalan dengan pendapat Sulistyorini (Sulistyorini et al., 2018) bahwa LKPD yang digunakan di sekolah pada umumnya hanya berisi daftar pertanyaan dalam bentuk essay dan peserta didik ditugaskan untuk menjawabnya. Tidak ada proses literasi dan pemecahan masalah sehingga belum mendorong tumbuhnya berpikir kritis pada diri peserta didik.

Tabel 6 Respon Peserta didik Terhadap Penggunaan LKPD Dikelas

\begin{tabular}{|c|c|c|c|}
\hline \multirow{2}{*}{ Item } & \multicolumn{2}{|c|}{ Persentase } & \multirow{3}{*}{$\begin{array}{c}\text { Kriteria } \\
\text { Sangat } \\
\text { Setuju }\end{array}$} \\
\hline & + & - & \\
\hline $\begin{array}{l}\text { Setiap pertemuan } \\
\text { pada proses } \\
\text { pembelajaran } \\
\text { Fisika guru selalu } \\
\text { memberikan } \\
\text { bahan ajar kepada } \\
\text { peserta didik }\end{array}$ & & $\begin{array}{c}85,45 \\
\%\end{array}$ & \\
\hline $\begin{array}{lr}\text { Bahan ajar } & \text { yang } \\
\text { diberikan } & \text { berupa } \\
\text { lembar } & \text { kerja } \\
\text { peserta } & \text { didik } \\
\text { (LKPD) } & \\
\end{array}$ & $79,09 \%$ & & $\begin{array}{l}\text { Sangat } \\
\text { Setuju }\end{array}$ \\
\hline $\begin{array}{lr}\text { Lembar } & \text { kerja } \\
\text { peserta } & \text { didik } \\
\text { (LKPD) } & \text { yang } \\
\text { diberikan } & \text { oleh } \\
\text { guru } & \text { belum } \\
\text { membantu } & \text { anda } \\
\text { untuk memahami } \\
\text { materi }\end{array}$ & & $\begin{array}{c}61,36 \\
\%\end{array}$ & Setuju \\
\hline
\end{tabular}

Gambaran respon peserta didik terhadap penggunaan model pembelajaran dikelas dieksplorasi menggunakan 2 pertanyaan dalam angket, seperti ditunjukkan pada tabel 5. Terlihat bahwa guru sudah banyak menerapkan metode dan model pembelajaran yang bervariasi salah 
satunya yaitu metode ceramah maupun model problem based learning. Hal ini ditunjukkan dengan respon peserta didik sebesar 66,36\% setuju dengan tanggapan tersebut. Akan tetapi walaupun sudah menunjukkan variasi model pembelajaran yang berbeda pada pembelajaran fisika masih ternyata masih $67,73 \%$ peserta didik menganggap bahwa model tersebut belum membantu peserta didik dalam memahami materi maupun menampilkan keterampilan proses peserta didik.

Tabel 7 Respon Peserta didik Terhadap Model Pembelajaran yang Diterapkan Dikelas

\begin{tabular}{|c|c|c|c|}
\hline \multirow{2}{*}{ Item } & \multicolumn{2}{|c|}{ Persentase } & \multirow{2}{*}{ Kriteria } \\
\hline & + & - & \\
\hline $\begin{array}{l}\text { Selama proses } \\
\text { pembelajaran fisika } \\
\text { guru menggunakan } \\
\text { metode ceramah , } \\
\text { model Problem Based } \\
\text { Learning } \\
\text { (pembelajaran } \\
\text { berbasis masalah), } \\
\text { atau lainnya. }\end{array}$ & $\begin{array}{c}66,36 \\
\%\end{array}$ & & Setuju \\
\hline $\begin{array}{lr}\text { Metode atau } & \text { model } \\
\text { yang digunakan oleh } \\
\text { guru } \\
\text { membantu } \\
\text { dalam } r \text { sudah } \\
\text { materi } & \text { anda } \\
\end{array}$ & $\begin{array}{c}67,73 \\
\%\end{array}$ & & Setuju \\
\hline
\end{tabular}

Gambaran respon peserta didik terhadap penggunaan media pembelajaran dikelas dieksplorasi menggunakan 3 pertanyaan dalam angket, seperti ditunjukkan pada tabel 6 . Terlihat bahwa guru sudah sering menggunakan media pembelajaran yang bervariasi salah satunya yaitu powerpoint dan video pembelajaran. Hal ini ditunjukkan dengan respon peserta didik sebesar $78,18 \%$ dan $69,55 \%$ setuju dengan tanggapan tersebut. Akan tetapi walaupun sudah menunjukkan variasi penggunaan media pembelajaran pada pembelajaran fisika ternyata masih 59,55\% peserta didik menganggap bahwa media tersebut belum membantu peserta didik dalam memahami materi maupun menampilkan keterampilan proses peserta didik.

Gambaran respon peserta didik terhadap kebutuhan LKPD model terbaru yaitu berbasis POE sebesar $75,91 \%$. Selain itu peserta didik juga membutuhkan media pembelajaran terbaru yang dapat mendukung LKPD berbasis POE ini agar lebih menunjukkan kebermanfaatannya yaitu dengan menggunakan media augmented reality yang sangat disetujui oleh peserta didik $(81,36 \%)$.

Tabel 8 Respon Peserta didik Terhadap Penggunaan Media Pembelajaran Dikelas

\begin{tabular}{|c|c|c|c|}
\hline \multirow{2}{*}{ Item } & \multicolumn{2}{|c|}{ Persentase } & \multirow{2}{*}{ Kriteria } \\
\hline & + & - & \\
\hline $\begin{array}{ll}\text { Guru } & \text { menggunakan } \\
\text { media } & \text { pembelajaran } \\
\text { saat } & \text { pembelajaran } \\
\text { Fisika } & \end{array}$ & $\begin{array}{c}78,18 \\
\%\end{array}$ & & $\begin{array}{l}\text { Sangat } \\
\text { Setuju }\end{array}$ \\
\hline $\begin{array}{lr}\text { Media } & \text { pembelajaran } \\
\text { yang } & \text { digunakan } \\
\text { berupa } & \text { Powerpoint } \\
\text { dan sejenisnya }\end{array}$ & $\begin{array}{c}69,55 \\
\%\end{array}$ & & Setuju \\
\hline $\begin{array}{lr}\text { Media } & \text { pembelajaran } \\
\text { seperti } & \text { PPT dan } \\
\text { sejenisnya } & \text { yang } \\
\text { digunakan } & \text { oleh guru } \\
\text { belum } & \text { membantu } \\
\text { anda } & \text { dalam } \\
\text { memahami materi }\end{array}$ & & $\begin{array}{c}59,55 \\
\%\end{array}$ & Setuju \\
\hline
\end{tabular}

Jadi, berdasarkan analisis dari angket kebutuhan peserta didik didapatkan bahwa 71,43 $\%$ peserta didik menjawab Setuju diperlukannya pengembangan Lembar Kerja Peserta Didik Berbasis Predict-Observe-Explain Berbantuan Augmented Reality untuk Melatihkan Keterampilan Proses Dasar, dengan nilai kevalidan 2,754 dalam kategori cukup valid dan nilai relialibitas alfa cronbach hitung 0,928 sehingga $\mathrm{r}$ hitung $>\mathrm{r}$ tabel $(\mathrm{dk} 53=0,2725)$ sehingga angket kebutuhan peserta didik reliabel. Selain itu untuk desain LKPD berbsis POE berbantuan augmented reality berdasarkan analisis reveiw dokumen LKPD, analisis observasi dan analisis angket kebutuhan diperoleh gambaran sebagai berikut, pada LKPD tahap predict akan ditampilkan pada awal LKPD sebagai hipotesis awal sebelum melakukan percobaan. Tahap observe dilakukan percobaan untuk membuktikan hipotesis. Sedangkan pada tahap explain disajikan beberapa pertanyaan untuk membandingkan predict dan observe. Pada LKPD augmented reality ditampilkan pada ilustrasi predict, tampilan alat dan bahan percobaan, serta langkah percobaan. Hal ini 
supaya peserta didik lebih memahami kegiatan percobaan yang akan dilakukan.

Tabel 9 Respon Peserta didik Terhadap LKPD Berbasis POE berbantuan augmented reality yang akan Dikembangkan

\begin{tabular}{|c|c|c|c|}
\hline \multirow{2}{*}{ Item } & \multicolumn{2}{|c|}{ Persentase } & \multirow{2}{*}{ Kriteria } \\
\hline & + & - & \\
\hline \begin{tabular}{ll}
\multicolumn{3}{l}{ Saya memerlukan LKPD } \\
terbaru yang dapat \\
membantu & lebih \\
memahami materi yang \\
diajarkan
\end{tabular} & $\begin{array}{c}75,00 \\
\%\end{array}$ & & $\begin{array}{l}\text { Sangat } \\
\text { Setuju }\end{array}$ \\
\hline $\begin{array}{l}\text { Saya memerlukan LKPD } \\
\text { berbasis POE } \\
\text { (menggunakan tahap } \\
\text { memprediksi, mengamati } \\
\text { dan menjelaskan) pada } \\
\text { proses pembelajaran } \\
\text { Fisika }\end{array}$ & $\begin{array}{c}75,91 \\
\%\end{array}$ & & $\begin{array}{l}\text { Sangat } \\
\text { Setuju }\end{array}$ \\
\hline $\begin{array}{l}\text { Saya tidak memerlukan } \\
\text { media pembelajaran } \\
\text { terbaru pada proses } \\
\text { pembelajaran Fisika }\end{array}$ & $\begin{array}{c}78,18 \\
\%\end{array}$ & & $\begin{array}{l}\text { Sangat } \\
\text { Setuju }\end{array}$ \\
\hline \begin{tabular}{l}
\multicolumn{3}{l}{ Saya memerlukan media } \\
pembelajaran berbasis \\
Augmented \\
(media memproyeksikan \\
benda maya menjadi \\
seperti nyata) sebagai \\
media terbaru untuk \\
membuat lebih semangat \\
dan tertarik belajar fisika
\end{tabular} & $\begin{array}{c}81,36 \\
\%\end{array}$ & & $\begin{array}{l}\text { Sangat } \\
\text { Setuju }\end{array}$ \\
\hline
\end{tabular}

Pengembangan ini diperkuat dengan hasil penelitian Hairudin (2013) bahwa penelitian menunjukkan hasil validasi lembar kegiatan peserta didik (LKPD) sebesar 90,2 \% dan berada pada kategori valid dan layak digunakan sehingga dapat disimpulkan bahwa LKPD berbasis POE dikembangkan pada mata pelajaran kimia kelas XI pokok bahasan koloid sudah valid atau sesuai dengan tuntutan kurikulum 2013. Sejalan dengan hal itu penggunaan augmented reality juga layak digunakan sebagai bantuan LKPD berbasis POE karena memiliki keunggulan seperti lebih interaktif, efektif dalam penggunaan, dapat diimplementasikan secara luas dalam berbagai media, modeling objek yang sederhana karena hanya menampilkan beberapa obyek dan mudah dioperasikan (2019) selain itu augmented reality dapat membut proses pembelajaran lebih menyenangkan dan membantu peserta didik untuk memahami materi pelajaran dengan mudah.

\section{KESIMPULAN}

Berdasarkan hasil penelitian diatas menunjukkan bahwa: (1) peserta didik merasa bosan dan tidak bersemangat dalam proses pembelajaran fisika sehingga kurangnya pemahaman dan keterampilan proses peserta didik terhadap materi yang diajarkan (2) LKPD, model pembelajaran dan media pembelajaran yang telah digunakan belum memaksimalkan peserta didik dalam memperoleh materi dan mengembangkan keterampilan proses peserta didik. Oleh karena itu diperlukannya LKPD terbaru dengan model dan media pembelajaran terbaru juga yaitu LKPD berbasis POE berbantuan augmented reality untuk melatihkan kemampuan proses dasar pada konsep fluida statis, (3) peserta didik memerlukan LKPD terbaru untuk melatihkan keterampilan proses dasar dalam proses pembelajaran fisika yaitu LKPD berbasis POE berbantuan augmented reality, (4) LKPD tahap predict akan ditampilkan pada awal LKPD sebagai hipotesis awal sebelum melakukan percobaan. Tahap observe dilakukan percobaan untuk membuktikan hipotesis. Sedangkan pada tahap explain disajikan beberapa pertanyaan untuk membandingkan predict dan observe. Pada LKPD augmented reality ditampilkan pada ilustrasi predict, tampilan alat dan bahan percobaan, serta langkah percobaan.

\section{UCAPAN TERIMA KASIH}

Peneliti mengucapkan terimakasih kepada ibu Yuli Widiastuti selaku guru fisika SMA Negeri 8 Kota Bengkulu yang telah memberikan izin untuk melakukan penelitian di sekolah serta semua peserta didik-siswi SMA Negeri 8 Kota Bengkulu yang telah membantu peneliti untuk melaksanakan penelitian ini. Selain itu, peneliti mengucapkan terimakasih juga kepada dosen serta teman-teman Pendidikan Fisika Universitas Bengkulu yang telah membantu dalam penulisan penelitian ini.

\section{DAFTAR PUSTAKA}

Anggraini, S. A. P., Lesmono, A. D., \& Handono, S. (2017). Pengembangan Lembar Kerja Siswa (LKS) Fisika Berbasis POE Materi Gerak Harmonis Sederhana di 
MAN. Seminar Nasional Pendidikan Fisika 2017, 2(1), 1-7.

Bakri, F., Rasyid, R., \& Mulyaningsih, R. D. A. (2015). Pengembangan Modul Fisika Berbasis Visual untuk Sekolah Menengah Atas (SMA). Jurnal Penelitian \& Pengembangan Pendidikan Fisika, 1(2), 67-74. https://doi.org/10.21009/1.01211

Fakhrudin, A., Yamtinah, S., \& Riyadi. (2019). Implementation of Augmented Reality Technology in Natural Sciences Learnings of Elementary School to Optimize the Students's Learning Result. International Journal of Indonesian Education and Teaching, 3(1), 1-10.

Hairudin, Herdini, \& Linda, R. (2013). Pengembangan Lembar Kegiatan Peserta Didik Berbasis Predict-Observe-Explain (POE) untuk Menunjang Pelaksanaan Kurikulum 2013 Pada Mata Pelajaran Kimia SMA Pokok Bahasan Koloid. Jurnal Online Mahasiswa Fakultas Keguruan Dan Ilmu Pendidikan, 3(1), 1-10.

Muna, I. A. (2017). Model Pembelajaran POE (Predict-Observe-Explain) dalam Meningkatkan Pemahaman Konsep dan Keterampilan Proses IPA. ElWasathiya:Jurnal

Studi Agama, 5(1), 73-91.

Mustaqim, I. (2016). Pemanfaatan Augmented Reality Sebagai Media Pembelajaran. Jurnal Pendidikan Teknologi Dan Kejuruan, 13(2), 174-183.

Ningrum, I. E., \& Suparman. (2017). Analisis Kebutuhan Bahan Ajar Matematika Berpendekatan Kontekstual. Prosiding Semnr Nasional Etnomatnesia, 698-701.
Putri, D. H., Risdianto, E., \& Sutarno. (2017). Identifikasi Keterlaksanaan Praktikum Fisika SMA dan Pembekalan Keterampilan Abad 21. Seminar Nasional Sains Dan Entepreneurship IV, 114-122.

Siahaan, A. D., Medriati, R., \& Risdianto, E. (2019). Pengembangan Penuntun Pratikum Fisika Dasar II Menggunakan Teknologi Augmented Reality pada Materi Rangkaian Listrik dan Optik Geometris. Jurnal Kumparan Fisika, 2(2), 91-98.

Sugiyono. (2010). Metode Penelitian Pendidikan. Alfabeta.

Sugiyono. (2013). Metode Penelitian Kombinasi (Mixed Methods). Alfabeta.

Sulistyorini, S., Harmanto, Abidin, Z., \& Jaino. (2018). Pengembangan Lembar Kerja Peserta Didik (LKPD) Tematik Terpadu Mengintegrasikan Penguatan Pendidikan Karakter (PPK) Dan Literasi Siswa Sd Di Kota Semarang. Jurnal Kreatif, 8(4), 138147.

Yudhi, P. (2017). Analisis Kebutuhan Pengembangan Lembar Kerja Siswa Berbasis Realistics Mathematics Education (Rme) Pada Materi Fpb Dan Kpk Untuk Siswa Kelas Iv Sekolah Dasar. Menara Ilmu, 9(74), 144-149.

Yusup, F. (2018). Uji Validitas dan Reliabilitas Instrumen Penelitian Kuantitatif. 7(1), 1723.

Zeila, W. Z., Hobri, \& Suharto. (2014). Pengembangan Perangkat Pembelajaran Matematika Berbantuan Komik POP UP dengan Model Problem Based Instruction (PBI) Sub Pokok Bahasan Kubus dan Balok untuk Siswa SMP Kelas VIII. Kadikma, 5(3), 69-78. 